Ярцева Светлана Владимировна, кандидат медицинских наук, доцент, кафедра госпитальной терапии с профпатологией, ГУ «Луганский государственный медицинский университет», кв. 50 лет Обороны Луганска, 1, г. Луганск, Украина, 91005

E-mail: yartsevasv@rambler.ru

Оленицкая Елена Степановна, кандидат медицинских наук, доцент, кафедра госпитальной терапии с профпатологией, ГУ «Луганский государственный медицинский университет», кв. 50 лет Обороны Луганска, 1, г. Луганск, Украина, 91005

E-mail: olenitskaya@yandex.ua

Мякоткина Галина Васильевна, кандидат медицинских наук, доцент, кафедра госпитальной терапии с профпатологией, ГУ «Луганский государственный медицинский университет», кв. 50 лет Обороны Луганска, 1, г. Луганск, Украина, 91005

E-mail: dz.ldmu@list.ru

Соколова Наталия Анатольевна, кандидат медицинских наук, асистент, кафедра госпитальной терапии с профпатологией, ГУ «Луганский государственный медицинский университет», кв. 50 лет Обороны Луганска, 1, г. Луганск, Украина, 91005

E-mail: dz.ldmu@list.ru

Стрекозова Инна Петровна, асистент, кафедра госпитальной терапии с профпатологией, ГУ «Луганский государственный медицинский университет», кв. 50 лет Обороны Луганска, 1, г. Луганск, Украина, 91005 E-mail: i.strekozova@mail.ru

Нетруненко Лилия Владимировна, асистент, кафедра госпитальной терапии с профпатологией, ГУ «Луганский государственный медицинский университет», кв. 50 лет Обороны Луганска, 1, г. Луганск, Украина, 91005

E-mail: netrunenko.gastro@yandex.ua

UDC: 616.711+616.832-06-036.4-089-092.4

DOI: $10.15587 / 2313-8416.2015 .42015$

\title{
ASSESSMENT OF EFFICIENCY OF EARLY DECOMPRESSION OF THE SPINAL CORD IN SPINAL INJURY BASED ON MORPHOLOGICAL AND STATISTICAL ANALYSIS
}

\section{(C) M. Salkov}

Study of the morphogenesis processes in tissues of a damaged spinal cord during different periods of trauma, conducting statistical analysis of surgical treatment during acuity and early periods allow evaluating the effectiveness of early decompression. The aim of this research was to study the processes of morphogenesis in the damaged tissues of spinal cord and to evaluate the development of secondary changes due to prolonged compression.

Methods: A comparative morphological study of macro- and micro-preparations of 10 corpses. Causes of death were: an ascending edema of a spinal cord - 4, a brain injury - 1, a heavy polytrauma - 2, somatic complications (a thromboembolic disease, a pneumonia) - 3. Results of surgical treatment of 3 groups of patients in the acuity and early postoperative periods were analyzed. A comparative analysis of 180 observations of surgical treatment of patients with spinal cord and cauda equina trauma in the first 3 days, from 3 to 7 days and 7 days to 3 weeks was conducted. Analysis was performed on the American Spinal Injury Association (ASIA) scale. Correlation between morphological and statistical data is performed.

Results: On the basis of the morphological analysis, progression of secondary changes of a spinal cord during prolonged compression was determined, which become irreversible on the 7th-8th day. Secondary trauma is less frank after conducting an early decompression. Based on the dynamics analysis of the operations timing and the ASIA scale neurological data dynamics it was established that the effectiveness of surgical treatment in the first two groups (first 6 days) correspond to $70 \%$, and in the third one (between 7 and 21 days) - $10 \%$.

Conclusions: Primary spinal cord injury, after prolonged compression, is accompanied by progressive secondary changes and as a result, irreversible changes in the structure and function of the spinal cord. Morphological study helps to explain the results of the statistical analysis and to determine the most effective surgery timing as a whole. Early intervention may prevent the spread of secondary damage

Keywords: spinal injury, secondary injury, spinal cord decompression 
Вивчення процесів морфогенезу в тканинах пошкодженого спинного мозку, проведення статистичного аналізу оперативного лікування в гострому та ранньому періодах дозволяє оиінити ефективність ранньої декомпресії. Проаналізовано результати морфологічного дослідження та хірургічного лікування пацієнтів із забоєм спинного мозку в шийному відділі

Ключові слова: спинальна травма, вторинна травма, декомпресія спинного мозку

\section{Introduction}

Study of the processes of morphogenesis in the tissues of the damaged spinal cord in different periods of injury, and statistical analysis of surgical treatment in acute and early periods allow assessment of efficiency of early decompression.

\section{Literature review}

Spinal cord injury has a biphasic course. Primary spinal cord injury occurs at the moment of injury directly, forming an area of contusion and compression of the medulla. Defects of the local vasculature, causing edema and hemorrhage in well-vascularized gray matter and to a lesser extent in the white matter, are observed. Paralysis of neurons involved in motor, sensory and autonomic function occurs in the area of injury. Secondary disaster occurs after the primary injury and leads to damage and death of neural cells. Generally, the progression of the second phase takes place during the first 24-48 hours. Vascular dysfunction, ischemia, glutamatergic excitotoxicity, inflammation and apoptosis are progressed in this period [1-12].

\section{Materials and methods}

A comparative morphological study of macro- and micro-slides of 10 bodies who died as a result of spinal cord injury in the cervical region was performed. Causes of death were: an ascending edema of a spinal cord -4 , a brain injury -1 , a heavy polytrauma -2 , somatic complications (a thromboembolic disease, a pneumonia) -3 . The results of surgical treatment of 3 groups of patients in the acute and early postsurgical periods were analyzed. A comparative analysis of 180 observations of the surgical treatment of patients with spinal cord and cauda equina injury during the first 3 days, from the $3^{\text {rd }}$ day to the $7^{\text {th }}$ day and from the $7^{\text {th }}$ day up to 3 weeks was performed. Analysis was performed based on the American Spinal Injury Association (ASIA) scale. Correlation between morphological and statistical data was performed. All morphological observations showed spinal cord compression. Intravital level of neurological disorders corresponded ASIA - A. Surgery was not performed in three cases. Decompressive laminectomy with dissection and duraplasty was performed in one case. On a section, laminectomy throughout the cervical spine was performed, the spinal cord was examined, macroscopic slides and block preparations of the damaged region of the spinal cord were prepared, then, microscopic studies - colour- ing all micro-slides with Ehrlich hematoxylin - eosin x7, x40 was conducted.

\section{Results}

Researches of preparations for 4, 7, 8, 71 days are indicative. In the study of the slides (preparations) of a patient who died on the $4^{\text {th }}$ day, the tension of the dura mater was revealed. Upon autopsy the brain was edematous, tense, overlaps the dura mater. In the study of macro-slides, an apparent edema was noted, the brain was wet, and the surface was shiny. Foci of brain detritus and areas of intramedullary hemorrhage were revealed. Tension of the dura mater was revealed. Upon autopsy the brain was edematous, tense, overlaps the dura mater. In the study of macro-slides, an apparent edema was noted, the brain was wet, and the surface was shiny. Foci of brain detritus and areas of intramedullary hemorrhage were revealed (Fig. 1).

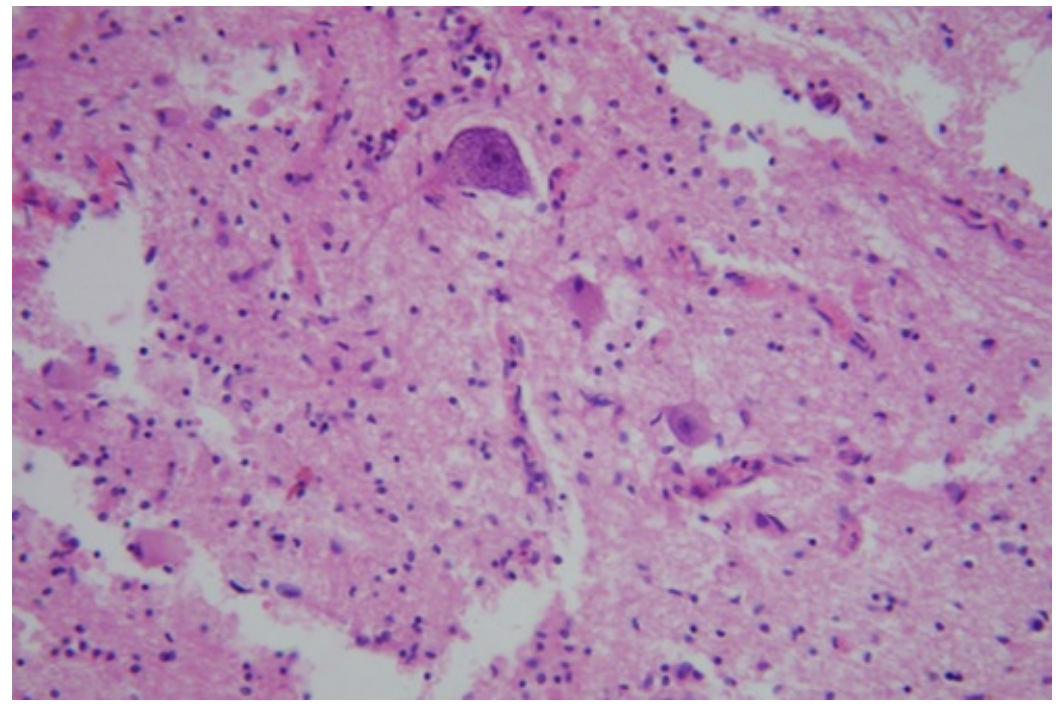

Fig. 1. Spinal cord injury, secondary changes at the level of $\mathrm{C} 3-\mathrm{C} 7$ (micro-slide). Death on the 4th day. Photomicrograph (original magnification, $\mathrm{x} 40$; hematoxylin-eosin [H-E] stain)

The study of the slides (preparations) of a patient who died on the $7^{\text {th }}$ day showed extension of ascending and descending edema. Macroscopically: shine and wetness of the surface were more apparent; medulla is looser and was significantly damaged during manipulation. Petechial hemorrhages are common throughout the edematous tissue, expansion of pericellular and perivascular spaces was observed. Edema of the cells and fibers, disintegration of the trunks, blood stasis with focal largecell infiltration around the vessels, hemolysis of blood in dilated vessels with necrotic changed wall, foci saturated with hemolyzed erythrocytes were apparent. Areas of edema with disintegration of groups of surviving ganglion cells were imaged. The vessels of the pia mater 
were full-blooded. Neurons were losing their nucleus; structure of the glial tissue was impaired, inflammatory changes were apparent (Fig. 2).

Secondary changes are most apparent in the patient who died on the $71^{\text {st }}$ day. Upon cutting the dura mater, medulla prolapses beyond its edges. However, the edema was less significant than in previous preparations, the medulla had more ordered structure, with no signs of hemorrhage. Vascular pattern was clearly imaged. Research of micro-slides showed different degree of ischemic changes. A significant amount of plasmoblast in surviving ganglion cells associated with the dead neurocytes appears. The cells had increased Nissl's granulosity. Regressive glial changes were significant, reduction in cellular composition. Serous fluid was in pericellular and perivasal spaces. Formation of ischemic cysts was occurred. Diffuse inflammatory infiltration was revealed in the edematous tissue of the meninges (Fig. 3).

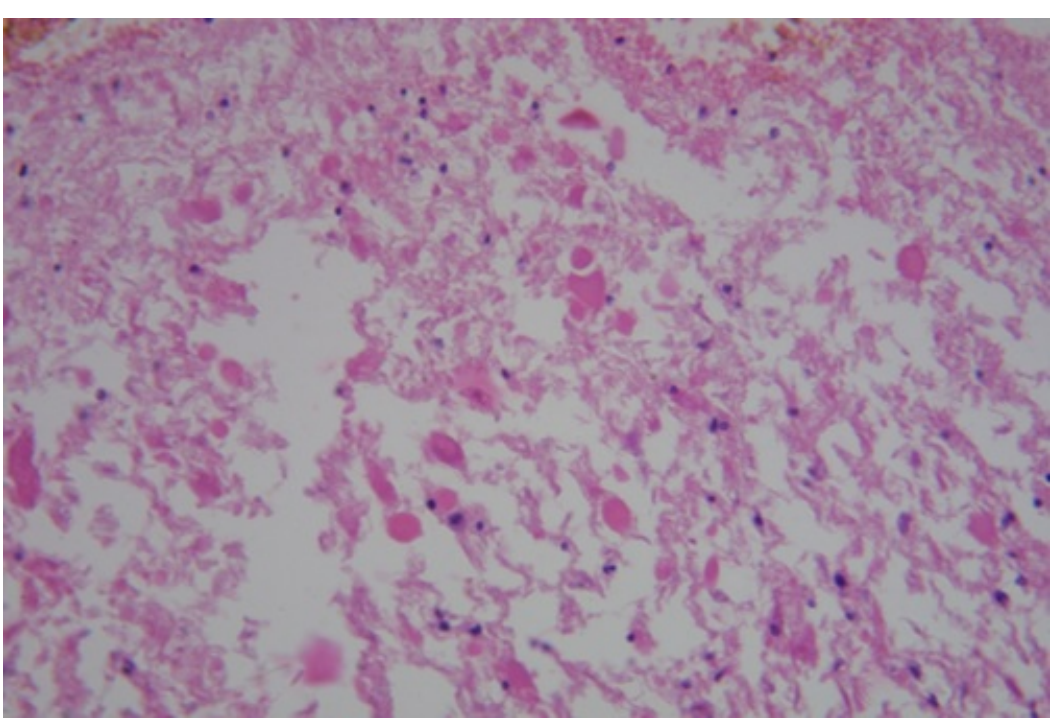

Fig. 2. Spinal cord injury, secondary changes at the level of C1-D1 (micro-slide). Death on the 7th day. Photomicrograph (original magnification, $\mathrm{x} 40$; hematoxylin-eosin [H-E] stain)

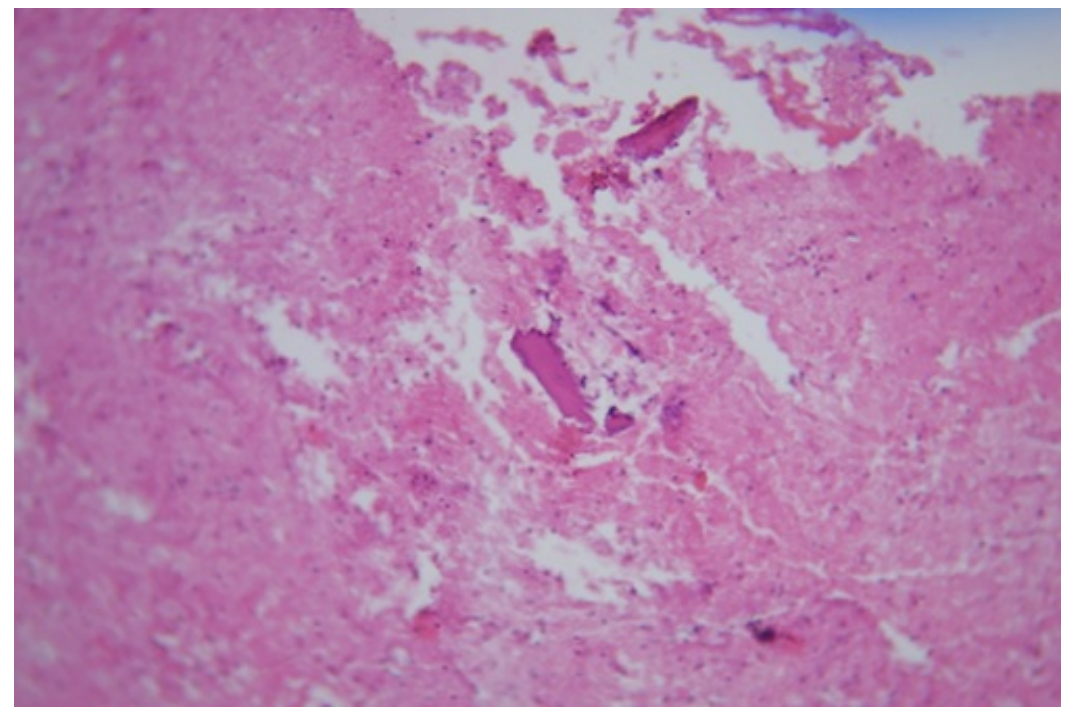

Fig. 3. Spinal cord injury, secondary changes at the level of C3-C7 (micro-slide). Death on the 71st day. Photomicrograph (original magnification, $\mathrm{x} 7$; hematoxylin-eosin [H-E] stain)
Death of the patient, who died on the $8^{\text {th }}$ day, was due to pulmonary embolism. Within the $1^{\text {st }}$ day, decompressive laminectomy of three vertebrae (C4-6) with dissection and duraplasty was performed.

In the study of macro-slides, an apparent edema was noted, the brain was wet, and the surface was shiny. Areas of intramedullary hemorrhage were revealed. Microscopically: the medulla had a spongy form, the increase of tissue fluid in interstitial, pericellular and perivasal spaces. Edema is limited to 3 segments; there is no ascending and descending edema. Petechial hemorrhages and areas of necrobiotic changes in the ganglion cells were widespread. Unlike previous studies, anatomical structure of glia, neurons with the presence of nuclei therein was preserved, the cellular composition was preserved best of all, and the edema was limited, indicating less significant secondary changes (Fig. 4).

On the basis of morphological analysis, the progression of secondary changes of the spinal cord during the prolonged compression, which become irreversible on the 7-8 day, was established.

An analysis of 180 patients who were operated in the Regional Clinical Hospital n. a. I. I. Mechnikov in Dnepropetrovsk, Krivoy Rog Municipal Clinical Hospital No.2, Odessa Municipal Clinical Hospital No.11 from 2008 to 2014 was performed. Evaluation of neurological status was carried out based on the ASIA scale.

Patients who had surgery within the first 3 days showed improvement noted in $69.6 \%$ (56 cases: cervical injury - 36; thoracic injury -12 ; lumbar injury -8 ).

Patients who had surgery between the $3^{\text {rd }}$ and the $7^{\text {th }}$ days showed improvement noted in $61.7 \%$ (34 cases: cervical injury - 16; thoracic injury - 10; lumbar injury -8$)$.

90 patients had surgery during the period from the $7^{\text {th }}$ day up to 3 weeks with an improvement noted in $10 \%$ (cervical injury - 49; thoracic injury - 19; lumbar injury -22). The reasons of late operation: brain injury, heavy polytrauma, somatic complications.

Morphological studies revealed that the secondary injury was less significant after the early decompression and proves low efficiency of decompression after 7-8 days. An analysis of the surgery timing and dynamics of neurological data on the ASIA scale showed that the efficiency of surgical treatment in the first two groups (first 6 days) reached $70 \%$, in the third group (between the $7^{\text {th }}$ and the $21^{\text {st }}$ days) reached $10 \%$ (Fig. 5). 


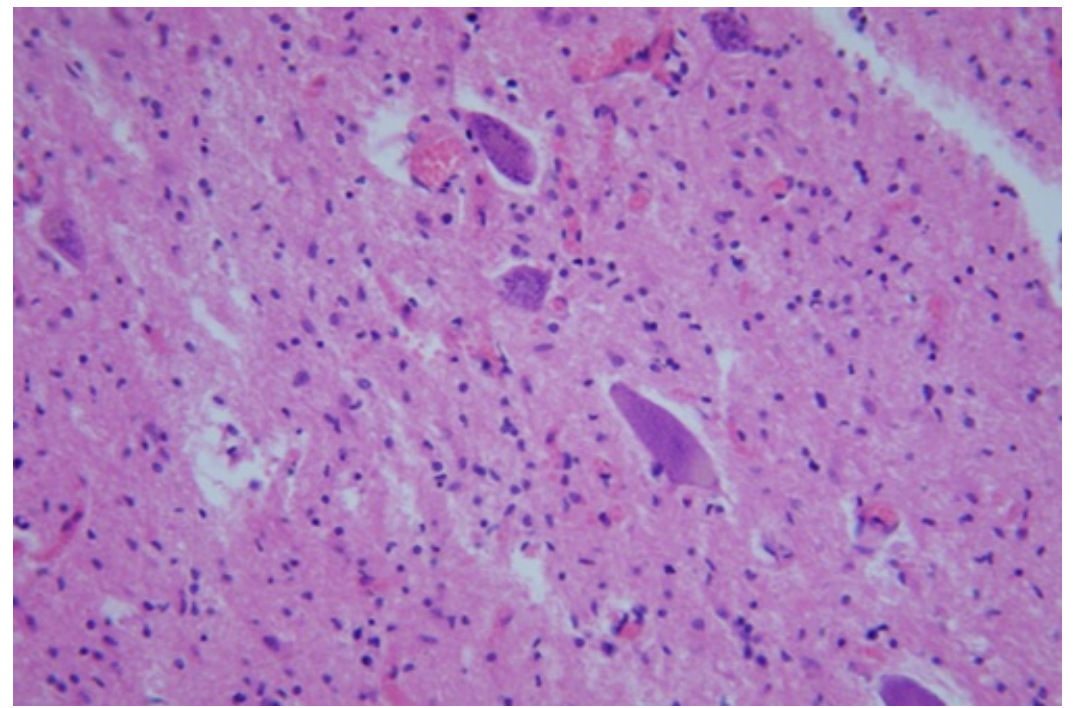

Fig. 4. Spinal cord injury, secondary changes at the level of C4-C6 (micro-slide). Death on the 8th day. Photomicrograph (original magnification, $\mathrm{x} 40$; hematoxylin-eosin [H-E] stain)

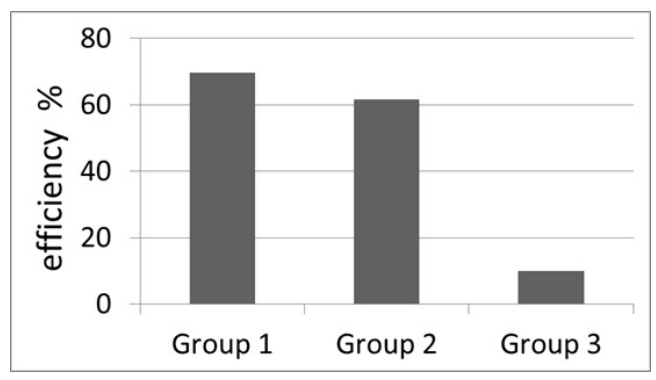

Fig. 5. Evaluation of surgery during the periods

\section{Discussion}

Most clinical studies show the high efficiency of early decompression of the spinal cord, which contributes to the improvement of neurological state [13-17].

Data of the early decompression efficiency are largely correlated to experimental studies [18-24].

The best results are observed in the event of a surgery made within the first 24-48 hours [14, 15, 25, 26].

Mirza et al. show improvement in the recovery of neurological disorders in patients that had surgery within the first 72 hours [27].

The study allows justifying the efficiency of early decompression on the basis of morphological and statistical data obtained. With the increase in the pre-surgical period, the number of unsatisfactory results of neurological recovery that increases sharply during decompression after 6 days from the date of injury rises.

It should be mentioned that a degree of the spinal cord compression not necessarily affected the level of development of secondary changes and neurological disorders. This discrepancy can be explained by a vascular factor causing the secondary injury globalization and is a criterion for further study of the issue.

\section{Conclusions}

Primary spinal cord injury, after prolonged compression, is accompanied by progressive secondary chang- es and as a result, irreversible changes in the structure and function of the spinal cord. Morphological study helps to explain the results of the statistical analysis and to determine the most effective surgery timing as a whole. Early intervention may prevent the spread of secondary damage.

\section{References}

1. Ackery, A. Inhibition of Fas - mediated apoptosis through administration of soluble Fas receptor improves functional outcome and reduces posttraumatic axonal degeneration after acute spinal cord injury [Text] / A. Ackery, S. Robins, M. G. Fehlings // Journal of Neurotrauma. - 2006. - Vol. 23, Issue 5. P. 604-616. doi: 10.1089/neu.2006.23.604

2. Brazda, N. Pharmacological modification of the extracellular matrix to promote regeneration of the injured brain and spinal cord [Text] / N. Brazda, H. W. Müller // Progress in Brain Research. - 2009. - Vol. 175. - P. 269281. doi: 10.1016/s0079-6123(09)17518-0

3. Buss, A. NG2 and phosphacan are present in the astroglial scar after human traumatic spinal cord injury [Text] / A. Buss, K. Pech, B. A. Kakulas, D. Martin, J. Schoenen, J. Noth, G. A. Brook // BMC Neurol. - 2009. Vol. 9, Issue 1. - P. 32. doi: 10.1186/1471-2377-9-32

4. Choo, A. Contusion, dislocation, and distraction: primary hemorrhage and membrane permeability in distinct mechanisms of spinal cord injury [Text] / A. M. Choo, J. Liu, C. K. Lam, M. Dvorak, W. Tetzlaff, T. R. Oxland // Journal of Neurosurgery: Spine. - 2007. - Vol. 6, Issue 3. - P. 255-266. doi: 10.3171 spi.2007.6.3.255

5. Cregan, S. P. Role of AIF in caspase - dependent and caspase - independent cell death [Text] / S. P. Cregan, V. L. Dawson, R. S. Slack // Oncogene. - 2004. - Vol. 23, Issue 16. - P. 2785-2796. doi: 10.1038/sj.onc.1207517

6. Donnelly, D. J. Inflammation and its role in neuroprotection axonal regeneration and functional recovery after spinal cord injury [Text] / D. J. Donnelly, P. G. Popovich // Experimental Neurology. - 2008. - Vol. 209, Issue 2. - P. 378-388. doi: 10.1016/j.expneurol.2007.06.009

7. Li, S. Novel injury mechanism in anoxia and trauma of spinal cord white matter: glutamate release via reverse $\mathrm{Na}+$ - dependent glutamate transport [Text] / S. Li, G. A. Mealing, P. Morley, P. K. Stys // J Neurosci. - 1999. - Vol. 19, Issue 14. - P. 16.

8. Nashmi, R. Changes in axonal physiology and morphology after chronic compressive ingury of the rat thoracic spinal cord [Text] / R. Nashmi, M. G. Fehlings // Neuroscience. - 2001. - Vol. 104, Issue 1. - P. 235-251. doi: 10.1016/ s0306-4522(01)00009-4

9. Shechter, R. Infiltrating blood-derived macrophages are vital cells playing an anti-inflammatory role in recovery from spinal cord injury in mice [Text] / R. Shechter, A. London, C. Varol, C. Raposo, M. Cusimano, G. Yovel et. al. // PloS Medicine. - 2009. - Vol. 6, Issue 7. - P. e1000113. doi: 10.1371/ journal.pmed.1000113

10. Shen, Y. PTPsigma is receptor for chondroitin sulfate proteoglucan, an inhibitor of neural regeneration [Text] / Y. Shen, A. P. Tenney, S. A. Busch, K. P. Horn, F. X. Cuascut, K. Liu, Z. He, J. Silver, J. G. Flanagan // Science. - 2009. Vol. 326, Issue 5952. - P. 592-596.

11. Tator, C. H. Review of the secondary injury theory of acute spinal cord trauma with emphasis on vascular mech- 
anisms [Text] / C. H. Tator, M. G. Fehlings // Journal of Neurosurgery. - 1991. - Vol. 75, Issue 1. - P. 15-26. doi: 10.3171/ jns.1991.75.1.0015

12. Tator, C. H. Update on pathophysiology and pathology of acute spinal cord injury [Text] / C. H. Tator // Brain Pathology. - 1995. - Vol. 5, Issue 4. - P. 407-413. doi: 10.1111/j.17503639.1995.tb00619.x

13. Fehlings, M. G. Early versus delayed decompression for traumatic cervical spinal cord injury: results of the Surgical Timing in Acute Spinal Cord Injury Study (STASCIS) [Text] / M. G. Fehlings, A. Vaccaro, J. R. Wilson, A. W. Singh, D. Cadotte, J. S. Harrop et. al. // PLoS ONE. - 2012. - Vol. 7, Issue 2. - P. e32037. doi: 10.1371/journal.pone.0032037

14. Fehlings, M. G. Current practice in the timing of surgical intervention in spinal cord injury [Text] / M. G. Fehlings, D. Rabin, W. Sears, D. W. Cadotte, B. Aarabi // Spine. 2010. - Vol. 35, Issue S21. - P. 166-173. doi: 10.1097/ brs.0b013e3181f386f6

15. Lenehan, B. Diversity and commonalities in the care of spine trauma internationally [Text] / B. Lenehan, M. F. Dvorak, I. Madrazo, Y. Yukawa, C. G. Fisher // Spine. - 2010. - Vol. 35, Issue S21. - P. 174-179. doi: 10.1097/brs.0b013e3181f32c82

16. Levi, L. Anterior decompression in cervical spine trauma: does the timing of surgery affect the outcome? [Text] / L. Levi, A. Wolf, D. Rigamonti, J. Ragheb, S. Mirvis, W. L. Robinson // Neurosurgery. - 1991. - Vol. 29, Issue 2. - P. 216-222. doi: 10.1227/00006123-199108000-00008

17. McKinley, W. Outcomes of early surgical management versus late or no surgical intervention after acute spinal cord injury [Text] / W. McKinley, M. A. Meade, S. Kirshblum, B. Barnard // Archives of Physical Medicine and Rehabilitation. - 2004. - Vol. 85, Issue 11. - P. 1818-1825. doi: 10.1016/ j.apmr.2004.04.032

18. Kobrine, A. I. Experimental acute balloon compression of the spinal cord: factors affecting disappearance and return of the spinal evoked response [Text] / A. I. Kobrine, D. E. Evans, H. V. Rizzoli // Journal of Neurosurgery. - 1979. - Vol. 51, Issue 6. - P. 841-845. doi: 10.3171/jns.1979.51.6.0841

19.Dolan, E. J. The value of decompression for acute experimental spinal cord compression injury [Text] / E. J. Dolan, C. H. Tator, L. Endrenyi // Journal of Neurosurgery. - 1980. Vol. 53, Issue 6. - P. 749-755. doi: 10.3171/jns.1980.53.6.0749

20. Guha, A. Decompression of the spinal cord improves recovery after acute experimental spinal cord compression injury [Text] / A. Guha, C. H. Tator, L. Endrenyi, I. Piper // Paraplegia. - 1987. - Vol. 25, Issue 4. - P. 324-339. doi: $10.1038 / \mathrm{sc} .1987 .61$

21. Nystrom, B. Spinal cord restitution following compression injuries in rats [Text] / B. Nystrom, J. E. Berglund // Acta Neurologica Scandinavica. - 1988. - Vol. 78, Issue 6. P. 467-472. doi: 10.1111/j.1600-0404.1988.tb03689.x

22. Zhang, Y. Time course of energy perturbation after compression trauma to the spinal cord: an experimental study in the rat using microdialysis [Text] / Y. Zhang, L. Hillered, Y. Olsson, A. Holtz // Surgical Neurology. - 1993. - Vol. 39, Issue 4. - P. 297-304. doi: 10.1016/0090-3019(93)90009-p

23. Delamarter, R. B. Pathophysiology of spinal cord injury. Recovery after immediate and delayed decompression [Text] / R. B. Delamarter, J. Sherman, J. B. Carr // J Bone Joint Surg Am. - 1995. - Vol. 77, Issue 7. - P. 1042-1049.

24. Carlson, G. D. Early time-dependent decompression for spinal cord injury: vascular mechanisms of recovery [Text] / G. D. Carlson, Y. Minato, A. Okada, C. D. Gorden, K. E. Warden, J. M. Barbeau et. al. // J Neurotrauma. - 1997. - Vol. 14, Issue 12. - P. 951-962. doi: 10.1089/neu.1997.14.951

25. Clohisy, J. C. Neurologic recovery associated with anterior decompression of spine fractures at the thoracolum- bar junction (T12-L1) [Text] / J. C. Clohisy, B. A. Akbarnia, R. D. Bucholz, J. K. Burkus, R. J. Backer // Spine. - 1992. Vol. 17, Issue S8. - P. 325-330. doi: 10.1097/00007632199208001-00019

26. McLain, R. F. Urgent surgical stabilization of spinal fractures in polytrauma patients [Text] / R. F. McLain, D. R. Benson // Spine. - 1999. - Vol. 24, Issue 16. - P. 16461654. doi: 10.1097/00007632-199908150-00005

27. Mirza, S. K. Early versus delayed surgery for acute cervical spinal cord injury [Text] / S. K. Mirza, W. F. III. Krengel, J. R. Chapman, P. A. Anderson, J. C. Bailey, M. S. Grady, H. A. Yuan // Clinical Orthopaedics and Related Research. - 1999. - Vol. 359. - P. 104-114. doi: 10.1097/00003086199902000-00011

\section{References}

1. Ackery, A., Robins, S., Fehlings, M. G. (2006). Inhibition of Fas-Mediated Apoptosis through Administration of Soluble Fas Receptor Improves Functional Outcome and Reduces Posttraumatic Axonal Degeneration after Acute Spinal Cord Injury. Journal of Neurotrauma, 23 (5), 604-616. doi: 10.1089/neu.2006.23.604

2. Brazda, N., Müller, H. W. (2009). Pharmacological modification of the extracellular matrix to promote regeneration of the injured brain and spinal cord. Progress in Brain Research, 175, 269-281. doi: 10.1016/s0079-6123(09)17518-0

3. Buss, A., Pech, K., Kakulas, B. A., Martin, D., Schoenen, J., Noth, J., Brook, G. A. (2009). NG2 and phosphacan are present in the astroglial scar after human traumatic spinal cord injury. BMC Neurol, 9 (1), 32. doi: 10.1186/1471-2377-9-32

4. Choo, A. M., Liu, J., Lam, C. K., Dvorak, M., Tetzlaff, W., Oxland, T. R. (2007). Contusion, dislocation, and distraction: primary hemorrhage and membrane permeability in distinct mechanisms of spinal cord injury. Journal of Neurosurgery: Spine, 6 (3), 255-266. doi: 10.3171/spi.2007.6.3.255

5. Cregan, S. P., Dawson, V. L., Slack, R. S. (2004). Role of AIF in caspase-dependent and caspase-independent cell death. Oncogene, 23 (16), 2785-2796. doi: 10.1038/sj.onc.1207517

6. Donnelly, D. J., Popovich, P. G. (2008). Inflammation and its role in neuroprotection, axonal regeneration and functional recovery after spinal cord injury. Experimental Neurology, 209 (2), 378-388. doi: 10.1016/j.expneurol.2007.06.009

7. Li, S., Mealing, G. A., Morley, P., Stys, P. K. (1999). Novel injury mechanism in anoxia and trauma of spinal cord white matter: glutamate release via reverse $\mathrm{Na}+-$ dependent glutamate transport. J Neurosci., 19 (14), 16.

8. Nashmi, R., Fehlings, M. (2001). Changes in axonal physiology and morphology after chronic compressive injury of the rat thoracic spinal cord. Neuroscience, 104 (1), 235-251. doi: 10.1016/s0306-4522(01)00009-4

9. Shechter, R., London, A., Varol, C., Raposo, C., Cusimano, M., Yovel, G. et. al. (2009). Infiltrating Blood-Derived Macrophages Are Vital Cells Playing an Anti-inflammatory Role in Recovery from Spinal Cord Injury in Mice. PLoS Medicine, 6 (7), e1000113. doi: 10.1371/journal.pmed.1000113

10. Shen, Y., Tenney, A. P., Busch, S. A., Horn, K. P., Cuascut, F. X., Liu, K., He, Z., Silver, J., Flanagan, J. G. (2009). PTPsigma is receptor for chondroitin sulfate proteoglucan, an inhibitor of neural regeneration. Science, 326(5952), 592-596.

11. Tator, C. H., Fehlings, M. G. (1991). Review of the secondary injury theory of acute spinal cord trauma with emphasis on vascular mechanisms. Journal of Neurosurgery, 75 (1), 15-26. doi: 10.3171/jns.1991.75.1.0015

12. Tator, C. H. (1995). Update on the Pathophysiology and Pathology of Acute Spinal Cord Injury. Brain Pathology, 5 (4), 407-413. doi: 10.1111/j.1750-3639.1995.tb00619.x

13. Fehlings, M. G., Vaccaro, A., Wilson, J. R., Singh, A., W. Cadotte, D., Harrop, J. S. et. al. (2012). Early ver- 
sus Delayed Decompression for Traumatic Cervical Spinal Cord Injury: Results of the Surgical Timing in Acute Spinal Cord Injury Study (STASCIS). PLoS ONE, 7 (2), e32037. doi: 10.1371/journal.pone. 0032037

14. Fehlings, M. G., Rabin, D., Sears, W., Cadotte, D. W., Aarabi, B. (2010). Current Practice in the Timing of Surgical Intervention in Spinal Cord Injury. Spine, 35 (S21), 166-173. doi: 10.1097/brs.0b013e3181f386f6

15. Lenehan, B., Dvorak, M. F., Madrazo, I., Yukawa, Y., Fisher, C. G. (2010). Diversity and Commonalities in the Care of Spine Trauma Internationally. Spine, 35 (S21), 174-179. doi: 10.1097/brs.0b013e3181f32c82

16. Levi, L., Wolf, A., Rigamonti, D., Ragheb, J., Mirvis, S., Robinson, W. L. (1991). Anterior Decompression in Cervical Spine Trauma: Does the Timing of Surgery Affect the Outcome? Neurosurgery, 29 (2), 216-222. doi: 10.1227/00006123199108000-00008

17. McKinley, W., Meade, M. A., Kirshblum, S., Barnard, B. (2004). Outcomes of early surgical management versus late or no surgical intervention after acute spinal cord injury. Archives of Physical Medicine and Rehabilitation, 85 (11), 18181825. doi: 10.1016/j.apmr.2004.04.032

18. Kobrine, A. I., Evans, D. E., Rizzoli, H. V. (1979). Experimental acute balloon compression of the spinal cord. Journal of Neurosurgery, 51 (6), 841-845. doi: 10.3171/ jns.1979.51.6.0841

19. Dolan, E. J., Tator, C. H., Endrenyi, L. (1980). The value of decompression for acute experimental spinal cord compression injury. Journal of Neurosurgery, 53 (6), 749-755. doi: 10.3171/jns.1980.53.6.0749

20. Guha, A., Tator, C. H., Endrenyi, L., Piper, I. (1987). Decompression of the spinal cord improves recovery after acute experimental spinal cord compression injury. Paraplegia, 25 (4), 324-339. doi: 10.1038/sc.1987.61

21. Nyström, B., Berglund, J.-E. (1988). Spinal cord restitution following compression injuries in rats. Acta Neurologica Scandinavica, 78 (6), 467-472. doi: 10.1111/j.1600-0404.1988. tb03689.x

22. Zhang, Y., Hillered, L., Olsson, Y., Holtz, A. (1993). Time course of energy perturbation after compression trauma to the spinal cord: An experimental study in the rat using microdialysis. Surgical Neurology, 39 (4), 297-304. doi: 10.1016/00903019(93)90009-p

23. Delamarter, R. B., Sherman, J., Carr, J. B. (1995). Pathophysiology of spinal cord injury. Recovery after immediate and delayed decompression. J Bone Joint Surg Am., 77 (7), 1042-1049.

24. Carlson, G. D., Minato, Y., Okada, A., Gorden, C. D., Warden, K. E., Barbeau, J. M. et. al. (1997). Early Time-Dependent Decompression for Spinal Cord Injury: Vascular Mechanisms of Recovery. Journal of Neurotrauma, 14 (12), 951-962. doi: 10.1089/neu.1997.14.951

25. Clohisy, J. C., Akbarnia, B. A., Bucholz, R. D., Burkus, J. K., Backer, R. J. (1992). Neurologic Recovery Associated with Anterior Decompression of Spine Fractures at the Thoracolumbar Junction (T12-L1). Spine, 17 (S8), 325-330. doi: 10.1097/00007632-199208001-00019

26. McLain, R. F., Benson, D. R. (1999). Urgent Surgical Stabilization of Spinal Fractures in Polytrauma Patients. Spine, 24 (16), 1646-1654. doi: 10.1097/00007632-199908150-00005

27. Mirza, S. K., Krengel, W. F., Chapman, J. R., Anderson, P. A., Bailey, J. C., Grady, M. S., Yuan, H. A. (1999). Early Versus Delayed Surgery for Acute Cervical Spinal Cord Injury. Clinical Orthopaedics and Related Research, 359, 104-114. doi: 10.1097/00003086-199902000-00011

Рекомендовано до публікаиії д-р мед. наук, професор Дзяк Л. А. Дата надходження рукопису 15.03.2015

Sal'kov Nikolai, PhD, Assistant, Department of Nervous Diseases and Neurosurgery, Dnipropetrovsk Medical Academy, str. Dzerzhinsky, 9, Dnepropetrovsk, Ukraine, 49044

E-mail:salkov@ua.fm

\section{УДК 617.55-001-036.227.616-001.18 \\ DOI: 10.15587/2313-8416.2015.41729}

\section{ЗАСТОСУВАННЯ НЕПАРАМЕТРИЧНОГО МЕТОДУ АНАЛІЗУ ВИЖИВАННЯ У ПОСТРАЖДАЛИХ ІЗ ЗАКРИТОЮ ПОЄДНАНОЮ АБДОМІНАЛЬНОЮ ТРАВМОЮ НА ФОНІ ПЕРЕОХОЛОДЖЕННЯ}

\section{(С) Г. Г. Рощін, О. О. Пенкальский, В. І. Іванов}

Проведено багатофакторний аналіз 180 постраждалих, які отримали закриту поєднану абдомінальну травму на фоні переохолодження. В рандомізованих групах постраждалих, з метою прогнозування перебігу травматичного процесу, застосовано непараметричний метод аналізу виживання по Каплану-Мейєру. Встановлено, щзо гіпотермія при поєднаній травмі є одним із факторів, які негативно впливають на виживаність постраждалих, щз потребує застосування комплексного лікування гіпотермії, особливо на догоспітальному та ранньому госпітальному етапах

Ключові слова: поєднана абдомінальна травма, гіпотермія, аналіз по Каплану-Мейєру

Hypothermia is the cause of elevated levels of systemic complications and mortality in patients with combined trauma. The development of systemic complications of hypothermia involves a violation of blood coagulation, metabolic acidosis, tissue hypoperfusion, hemodynamic instability. Hypothermia, acidosis and coagulopathy considered "lethal triad" in patients with combined trauma. 